\title{
Guidebook for renal dialysis patients: care of central venous catheters and arteriovenous fistula
}

\author{
Cartilha para o paciente em diálise renal: cuidados com cateteres venosos centrais e fístula arteriovenosa
}

Cuadernillo para el paciente en diálisis renal: cuidados con catéteres venosos centrales y fístula arteriovenosa

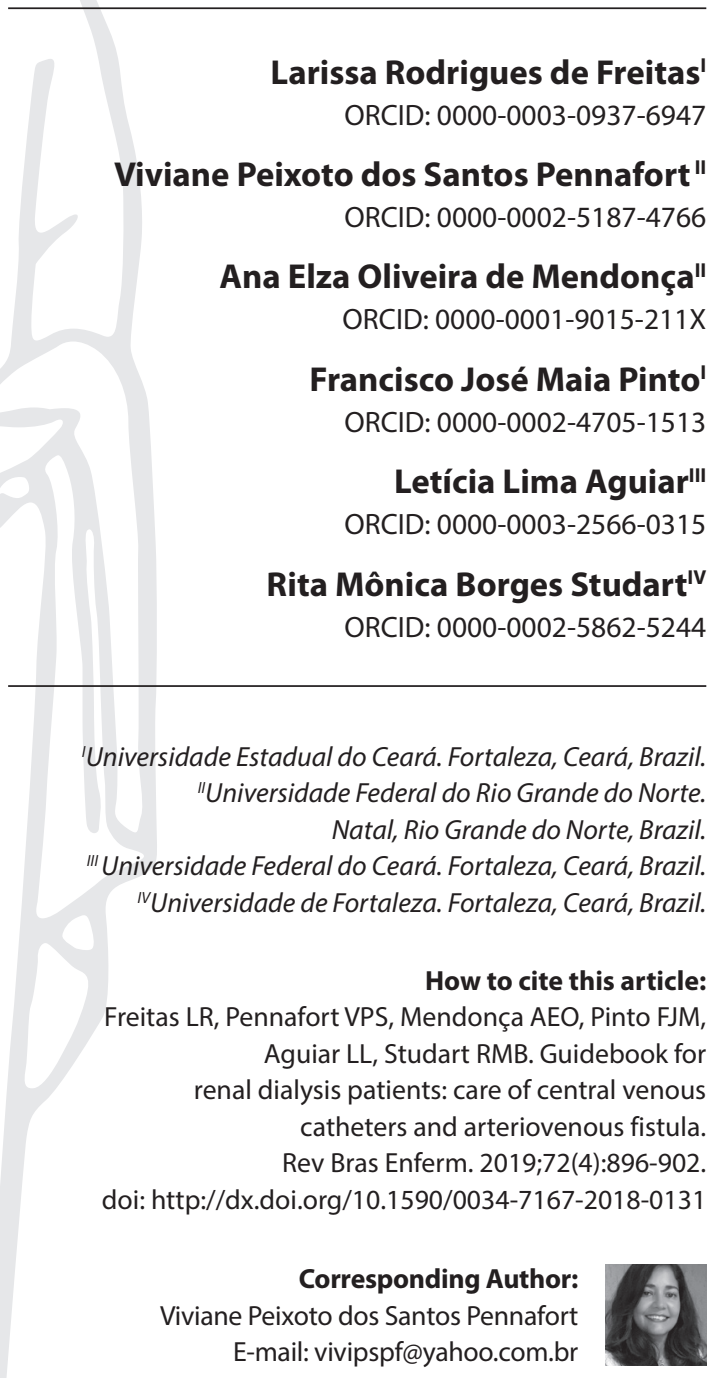

Submission: 03-20-2018 Approval: 10-22-2018

\section{ABSTRACT}

Objective: To design and validate the content and format of a guidebook for chronic renal failure patients about the care with venous access for hemodialysis at home. Method: Methodological study, in which the steps for the guidebook design were: project planning, literature search, material content, and qualification selection. Results: After analysis of the articles, the content to be included in the guidebook was selected. The first draft of the guidebook was submitted for content and format validation, with the participation of 12 specialists. The necessary adjustments for the design of the final version were made with the help of an illustrator. Conclusion: The designed guidebook, "Hemodialysis: Care of Venous Accesses and Intercurrences at Home," consists of educational material to help hemodialysis patients with daily care with central venous catheter and arteriovenous fistula practices in case of intercurrences.

Descriptors: Validation Studies; Renal Dialysis; Educational Technology; Arteriovenous Fistula; Catheterization, Central Venous.

\section{RESUMO}

Objetivo: construir e validar o conteúdo e a aparência de uma cartilha para o paciente renal crônico acerca dos cuidados com os acessos venosos para hemodiálise no domicílio. Método: estudo metodológico cujas etapas para construção da cartilha foram: elaboração do projeto, busca na literatura, escolha do conteúdo e qualificação do material. Resultados: após análise dos artigos encontrados, selecionou-se o conteúdo para compor a cartilha. A primeira versão da cartilha foi encaminhada para o processo de validação de conteúdo e aparência, com a participação de 12 especialistas. Atendeu-se às alterações necessárias, com auxílio do ilustrador, para confecção da versão final. Conclusão: a cartilha construída, Hemodiálise - Cuidados com acessos venosos e suas intercorrências no domicílio, consiste em um material educativo capaz de auxiliar o paciente em hemodiálise nos cuidados diários com o cateter venoso central ou fístula arteriovenosa e nas condutas, em casos de intercorrências.

Descritores: Estudos de Validação; Diálise Renal; Tecnologia Educacional; Fístula Arteriovenosa; Cateteres Venosos Centrais.

\section{RESUMEN}

Objetivo: Construir y validar en contenido y apariencia un cuadernillo para el paciente renal crónico, respecto del cuidado de los accesos venosos para hemodiálisis en el domicilio. Método: Estudio metodológico. Las etapas para construir el cuadernillo fueron: elaboración del proyecto; búsqueda en la literatura; elección del contenido; y calificación del material. Resultados: Luego de analizarse los artículos encontrados, se seleccionó el contenido que integraría el cuadernillo. La primera versión del cuadernillo fue remitida a proceso de validación de contenido y apariencia, del que participaron 12 especialistas. Fueron consideradas las alteraciones necesarias con ayuda del ilustrador para confeccionar la versión final. Conclusión: El cuadernillo construido, "Hemodiálisis - Cuidado de los accesos venosos y complicaciones domiciliarias" constituye un material educativo capaz de ayudar al paciente en hemodiálisis con los cuidados diarios del catéter venoso central o fístula arteriovenosa, y en las conductas en caso de producirse complicaciones.

Descriptores: Estudios de Validación; Diálisis Renal; Fístula Arteriovenosa; Cateterismo Venoso Central. 


\section{INTRODUCTION}

Chronic noncommunicable diseases (CNCDs) have been on the rise in Brazil, with $72 \%$ of deaths reported in 2007. As a result, the county has been putting into practice policies to prevent these diseases ${ }^{(1)}$. Chronic renal disease (CRD) is characterized by the presence of a renal lesion or a decrease in kidney function, which takes place slowly and irreversibly ${ }^{(2)}$.

Among the main causes for the development of CRD are high blood pressure and diabetes mellitus. The estimation is that, on average, 122,825 renal patients are treated a year, with a greater prevalence in those between 45 and 64 years old, of which $57 \%$ are male. Nearly 39,710 patients were submitted to dialysis in Brazil in 2016. Furthermore, $92.1 \%$ of the patients sought hemodialysis as their dialysis modality, which requires access for its realization, whether through the central venous catheter or an arteriovenous fistula ${ }^{(3)}$.

The nursing staff carries out the treatment of chronic renal patients in a more present manner. Their responsibility is also to capacitate and provide self-care guidance, through the identification of the needs of chronic renal patients undergoing the treatment, and by providing self-care orientation and strategies ${ }^{(4)}$.

In general, patients having difficulty understand the chronicity of the illness and its pharmacological needs, especially with poor social support, do not seek treatment or give it up for not having achieved their objectives and goals. In such situations, patients are not in a position to carry out their self-care on their own $\mathrm{n}^{(5)}$.

From this perspective, self-care may be carried out by patients themselves, as long as guidance and capacitation for the necessary care to be performed are provided, as well as an awareness of their own limitations.

Therefore, the implementation of a guidebook to provide orientation to patients undergoing hemodialysis treatment would help with adherence to the new routines the treatment demands, such that patients could consult the manual when facing doubts.

Consequently, lifestyle changes imply a decrease in infection rates and lower costs, because they prevent the implementation of new catheters or the preparation of new fistulas ${ }^{(6)}$. Although the patient is the main agent of his/her own treatment, the nurse intervenes beyond mere care, playing an important role as an educator that provides hemodialysis guidance and access care, thus facilitating self-care promotion.

The guidebook on hemodialysis access for patients undergoing such treatment came about after a field study carried out in 2014 with chronic renal patients that performed hemodialysis access at home.

It was noted that patients experienced a sense of anxiety and insecurity conducting vascular accesses for hemodialysis at home ${ }^{(7)}$. From this research came the following question: What precautions are recommended for chronic renal patients to maintain the central venous catheter and the arteriovenous fistula for the prevention of complications?

Therefore, this study focused on the design of educational technology in a guidebook format to help patients take care of venous accesses for hemodialysis and to provide information about actions to be taken in case of intercurrences at home.

The guidebook can be used by adult patients undergoing hemodialysis treatment, and those who seek to clarify doubts related to care with hemodialysis catheters and arteriovenous fistulas, including those who wish to learn more and carry out possible intercurrences at home.

\section{OBJECTIVE}

To design and validate the content and format of a guidebook for chronic renal failure patients about caring for venous accesses for hemodialysis at home.

\section{METHODS}

\section{Ethical aspects}

The study strictly followed the ethical and legal principles set out by Resolution 466/2012 from the National Health Council on research involving human beings. ${ }^{(8)}$

\section{Design, place of study, and duration}

The study's methodology developed according to the following steps: the development, validation, and assessment of research tools and the instrument.(9-10) The research was designed based on a conclusion in a paper for an undergraduate course, in which the need for guidance for patients using venous accesses for hemodialysis was acknowledged. The design took place between 2015 and 2016 during a nephrology nursing specialization course.

\section{Study protocol}

The guidebook design and validation process took the following steps: project design, literature search, material content, and qualification selection ${ }^{(10)}$.

After a literature analysis, the content to be included in the guidebook was selected in a clear and objective fashion. Subsequently, following the guidance of the researchers and with the help of a graphic designer, the guidebook images, design and, finally, layout were developed.

The illustrations were designed in a format that could be interpreted even without the text. However, the description of the care substantiated by the literature review was maintained, using accessible and culturally appropriate language, easily understandable even by the illiterate population.

After the design of the first draft, the guidebook was submitted to a content and format validation process, necessary to boost the reliability of the product. This was adapted from a model proposed for content validation, which consisted of the opinion of specialists on the adequacy of the guidelines related to care with hemodialysis access ${ }^{(11-12)}$. The invitation was formalized by convenience. After accepting to participate in the research, the specialists received the material for evaluation.

The informed consent form was sent by email, along with the first draft of the guidebook and a link to access a free Google Doc form, which allowed the design of forms and prompt share. The form addressed the characterization of the specialists, content relevance, and guidebook format.

The guidebook was sent to 16 specialists, 13 nurses, and 3 publicists. During the process, four specialists did not answer 
the invitation to participate in the study. Therefore, the material was evaluated by 12 specialists.

For the entire validation process, a four-point Likert scale for content and format reliability was used, from 1 (inadequate) to 4 (very adequate).

\section{Sample: professional eligibility criteria for the formation of the panel of skilled specialist}

For the selection of the specialists, professionals in nephrology nursing, with experience in the field and preferably a masters' or $\mathrm{PhD}$, were selected after an analysis of CVs submitted to the Lattes platform. The strategy used in this database was: PhDs and other researchers; search mode - topic (title or work keyword): specialization in nephrology nursing. For the selection of specialized nurses, CVs were analyzed based on Fehring criteria ${ }^{(7)}$, establishing a minimum score of five points to form the panel of experts, according to Chart 1.

Chart 1 - Fehring criteria for skilled nurse selection, Fortaleza, Ceará, Brazil, 2016

\begin{tabular}{|l|c|}
\hline Critérios & Pontos \\
\hline PhD in nursing & 4 \\
\hline Masters' in nursing & 3 \\
\hline Clinical practice with at least one year of hemodialysis & 3 \\
\hline Nephrology nursing specialization & 3 \\
\hline Higher education teaching & 3 \\
\hline Article published in a journal in the field of nephrology nursing & 2 \\
\hline $\begin{array}{l}\text { Participation in scientific events in the field of nursing or } \\
\text { nephrology nursing }\end{array}$ & 1 \\
\hline Works presented in the field of nephrology nursing & 1 \\
\hline Abstracts published in the field of nephrology nursing & 1 \\
\hline
\end{tabular}

Source: adapted from Fehring 1987.

Subsequently, a search was conducted for the emails of the selected specialists, based on their CVs and the sites of their institutions. More than three marketing experts were invited by convenience to contribute image analyses and respective terms. Thus, the examining panel was to have a total of 16 specialists.

\section{Result analysis and statistics}

The content validity index (CVI) was used to assess the agreement score among evaluators related to tool aspects and respective items.

A value greater than or equal to 0.78 was considered ${ }^{(11)}$.

$$
\mathrm{CVI}=\frac{\text { Number of answers " } 3 \text { " or "4" }}{\text { Total number of answers }}
$$

For the format validation, the specialists evaluated the images in relation to the layout, i.e., whether they were impressive, relevant to the content, straightforward, and objective.

As for the content evaluation, it was asked whether the content was appropriate to the target audience; followed a logic sequence; was straightforward, objective, scientifically correct, well-structured, and in accordance with accepted spelling; if the text corresponded to the level of audience knowledge, as well as the information on the front cover and back cover; and if the number of pages, title, and topics were appropriate.

\section{RESULTS}

\section{Description of the designed guidebook}

The first draft of the guidebook submitted to the validation process had 17 pages; it was printed in white and light green colors, on couche matte paper, with the title "Hemodialysis: Renal Patient Guidebook."

The guidebook content included an initial presentation and subsequent summary addressing the following issues: What Is Hemodialysis, Symptoms, Medical Evaluation, The Hemodialysis Machine, Arteriovenous Fistula Preparation, The Hemodialysis Catheter, Care with Arteriovenous Fistula Preservation, General Care with the Hemodialysis Catheter, Intercurrences at Home, and References.

For the content elaboration of the guidelines, the focus was on the use of short sentences and straightforward language for better understanding and adherence to the reading.

With the aim of reaching out to an adult audience, whether literate or not, the use of images that conveyed the content was the option. Therefore, care was taken in the elaboration of the images, such that the patient could look at them and understand.

\section{Educational guidebook validation process}

Twelve specialists participated in the final guidebook validation sample. Of these, nine were nurses, who attained a score between 8 and 11 points, according to the adapted Fehring criteria ${ }^{(11)}$, and all of them had experience in the area of renal patient care, with an average of 15 years of training. Regarding professional qualifications, four (58.3\%) had a specialization, three (25\%) had a master's degree, and two (16.7\%) had a PhD. The three marketing experts had an average of four years of experience, and all held specialist titles.

Initially, the specialists assessed the guidebook content (Table 1).

During the content evaluation stage, some items were assessed as being inadequate, as were others that attained a CVI score lower than the expected value (0.78).

Regarding topics 3 (The content is conveyed straightforwardly and objectively), 4 (The information is scientifically accurate), and 6 (The writing style corresponds to the level of the target audience's knowledge), only one evaluator assessed these items as inadequate, but that evaluator did not justify this assessment. Taking into account the evaluation of the other evaluators, these items were assessed as being valid, since they had higher percentages of being assessed as adequate or very adequate.

As for items 7 (Information on the cover and back cover and the presentation are coherent) and 9 (The title and topics are adequate), one evaluator suggested a change in the title wording, because in the first draft the word "Hemo-dialysis" was hyphenated. This suggestion was agreed to, and title came up with a better aspect.

Therefore, taking into account the feedback of the other evaluators on all assessed items, the validation was approved, since the overall assessment was satisfactory, with an overall CVI score of 0.84 . 
Table 1 - Evaluation of the guidebook content by specialists, Fortaleza, Ceará, Brazil, 2016

\begin{tabular}{llccc}
\hline Content & $\begin{array}{c}\text { Partially } \\
\text { Inadequate } \\
\mathbf{n}(\%)\end{array}$ & $\begin{array}{c}\text { Adequate } \\
\text { inadequate } \\
\mathbf{n}(\%)\end{array}$ & $\begin{array}{c}\text { Very adequate } \\
\mathbf{n}(\%) \\
\mathbf{n}(\%)\end{array}$ \\
\hline CVI
\end{tabular}

Table 2 - Evaluation the guidebook illustrations by specialists, Fortaleza, Ceará, Brazil, 2016

\begin{tabular}{|c|c|c|c|c|c|}
\hline Illustrations & $\begin{array}{c}\text { Inadequate } \\
\text { n (\%) }\end{array}$ & $\begin{array}{l}\text { Partially inadequate } \\
\mathrm{n}(\%)\end{array}$ & $\begin{array}{c}\text { Adequate } \\
\text { n (\%) }\end{array}$ & $\begin{array}{c}\text { Very adequate } \\
\mathrm{n}(\%)\end{array}$ & CVI \\
\hline 1. Are expressive and sufficient. & - & $1(8.3)$ & $3(25.0)$ & $8(66.7)$ & 0.91 \\
\hline 2. Are relevant to the content. & - & - & $5(41.7)$ & $7(58.3)$ & 1 \\
\hline 3. Are straightforward and convey the content. & - & - & $5(41.7)$ & $7(58.3)$ & 1 \\
\hline 4. The captions applied to the images are adequate. & - & $1(8.3)$ & $6(50.0)$ & $5(41.7)$ & 0.91 \\
\hline
\end{tabular}

Regarding the illustrations, none of the specialists classified the items as inadequate. Eight (66.7\%) evaluators indicated that the images were expressive and sufficient, leading to a CVI score of 0.91 ; seven $(58.3 \%)$ classified them as straightforward and with backed-up and relevant content, leading to a CVI score of 1 .

At this stage, the overall CVI score was 0.96 , thus achieving the research objective, which was to design a straightforward and expressive guidebook, from which the patient could understand the images with no need to rely on the description.

For pages 6 and 7 of the guidebook, image and text reorganization was suggested in order to be more objective and straightforward. The suggestion was agreed to, and the illustration designer was asked to change the positioning to provide for smoother reading.

One evaluator suggested that on page 8 the importance of the capillary should be highlighted, because there was not much explanation of the equipment and the machine. The recommendation was accepted, because it is important for the patient to understand the hemodialysis system, especially the dialyzer, which is responsible for filtering the blood.

A further suggestion related to the same page was the creation of another to refer to the medical evaluation, and to better describe the relevance of this evaluation and the exams to be carried out. The suggestion was accepted by creating a new page addressing the importance of the medical appointment, but not describing the exams, since this content did not represent the profile of the guidebook.

For page 9, which highlighted the sites for the fistula preparation, the inclusion of technical terms was recommended, because they were already mentioned when the issue related to catheters was addressed. The recommendation was not accepted, since the terms are complicated and are not often used in dialogues with the patient.

On page 10, while explaining the sites for catheter implantation, the inclusion of the term "vein" was suggested, because in the first draft the term "catheter in the jugular" was used, thus the term "catheter in the jugular vein" was accepted.

On page 11, the inclusion of the term "fremitus" was suggested, where the orientation is to "feel the presence of the fremitus daily." The recommendation was accepted, adding the word "vibration" in parentheses to clarify the meaning of the term.

For the item evaluating the motivation for reading, there were similarities in the percentages applied to the scale between "partially adequate" and "very adequate." Both items attained $58.3 \%$ approval and a CVI score of 0.91. Regarding this stage, the evaluators did not make any consideration.

For the evaluation related to the guidebook's cultural adequacy, the evaluators considered it very adequate, with a total $\mathrm{CVI}$ score of 0.95 . Therefore, the material achieved the objective of providing comprehensible language for the target audience.

Table 3 - Specialists' evaluation of the motivation for reading the guidebook, Fortaleza, Ceará, Brazil, 2016

\begin{tabular}{lcccc}
\hline Motivation & $\begin{array}{c}\text { Inadequate } \\
\mathbf{n}(\%)\end{array}$ & $\begin{array}{c}\text { Partially } \\
\text { inadequate } \\
\mathbf{n}(\%)\end{array}$ & $\begin{array}{c}\text { Adequate } \\
\mathbf{n}(\%)\end{array}$ & $\begin{array}{c}\text { Very adequate } \\
\mathbf{n}(\%)\end{array}$ \\
\hline 1. The content is motivating and stimulates continue reading. & - & $1(8.3)$ & $4(33.3)$ & $7(58.3)$ \\
2. The content stimulates interest. & - & $1(8.3)$ & $4(33.3)$ & $7(58.3)$ \\
\hline
\end{tabular}


After considering relevant the recommendations provided by the specialists, and at the conclusion of the analysis and evaluation of the items, the graphic designer was asked to review the design of the final version of the guidebook, as shown in Figure 1.
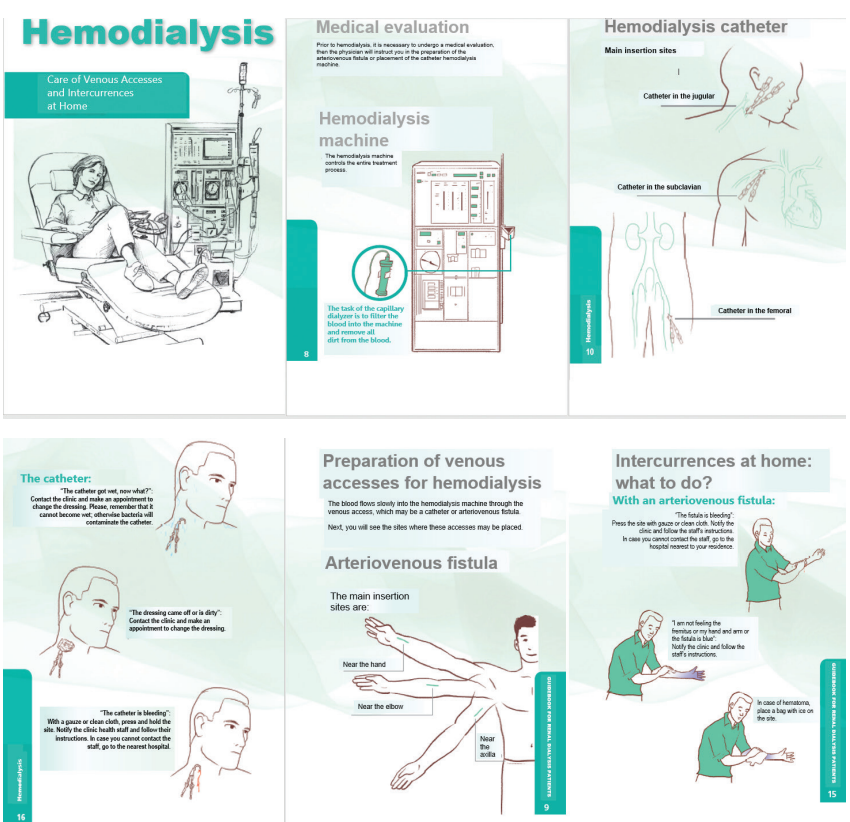

Figure 1 - Illustration of the corrected version of the guidebook "Hemodialysis: Care of Venous Accesses and Intercurrences at Home," Fortaleza, Ceará, Brazil, 2016

\section{DISCUSSION}

Cases of chronic renal disease in the dialysis stage have increased each year, and hemodialysis is the renal replacement therapy modality most used. Therefore, it requires patients to have efficient vascular access to carry out the treatment, through arteriovenous fistulas or central venous catheters. One of the greatest challenges is to maintain these accesses pervious and free of infections ${ }^{(3-13)}$.

Despite the low incidence of infection related to the use of autogenous arteriovenous fistulas, when it does take place, it can trigger severe clinical conditions, such as rupture and abundant bleeding. Most of the time, there is a need for debridement with fistula ligation and, eventually, the feeding artery itself to stop the hemorrhage. The central venous catheters are more susceptible to infections, which can reach the bloodstream more easily and evolve rapidly into septicemia and endocarditis. The care by dialysis services of vascular accesses in chronic renal patients must be constant, in order to minimize complications and prolong their usage time ${ }^{(13)}$.

One study showed that chronic renal patients has knowledge about the care of the accesses; however, this is limited to "do not wet the catheter and do not sleep or carry weight with the arm with the fistula." Regarding nursing staff performance, the reports pointed out that some patients were not properly advised about the care of the hemodialysis access; in contrast, some emphasized the concern of professionals about its maintenance and the prevention of complications ${ }^{(7)}$.
As a result, well-prepared educational material may provide support for the promotion of a critical and reflective attitude, turning certain discourses explicit rather than a reproduction of negative and uncritical representations, based on the hegemonic discourse systems of the society ${ }^{(14)}$. The development of the educational material must go beyond written and summarized ideas put into a paper and delivered to the patient. It is important to understand the population and get experienced professionals involved in the elaboration of high-quality didactic material ${ }^{(15)}$.

Consequently, creative educational technologies disseminate information more easily, facilitating the understanding and the involvement of renal patients in hemodialysis using self-care of vascular access, in turn optimizing the work of the multidisciplinary team.

Specialists considered the issues and the proposed content relevant to educational actions for the renal patient undergoing hemodialysis, as well as the guidelines related to home care of the venous accesses.

However, three items related to content evaluation (content adequacy, information flow, and writing style related to the level of the target audience's knowledge) attained a CVI score of 0.75 , which was considered inadequate, with no justification for such a score. Therefore, some flowery terms were replaced by straightforward words. Although these items had not attained a CVI score of 0.78 , the total CVI corresponding to the content was 0.84 ; therefore, it was considered validated by the specialists. In this case, the clinical validation proposed in the prior stage will be fundamental to assure patient comprehension of the cited items. Therefore, the need to convey easily understandable messages in order for the information to be properly grasped was corroborated, in order to avoid wrong interpretations ${ }^{(16)}$.

Regarding the format, which had a total CVI score of 0.96 , the evaluators considered the images expressive and easy to grasp, and thought they allowed patients, whether illiterate or not, to assimilate the knowledge. The repositioning of some figures and the insertion of an image of the dialyzer was suggested, since the equipment is indispensable for hemodialysis treatment and responsible for filtering the blood. Despite the emphasis on the care of vascular accesses, the suggestion was accepted for the final version of the guidebook, considering that the information is relevant to adherence to the treatment.

It is important to note that the illustrations help to focus attention and provide rich details to the educational material, thus supplementing the purpose of the text. As the graphics represent well each detail discussed in the text, they exemplify and bring the reader closer to the information to be learned, while strengthening memory as it combines a fact with a corresponding image $\mathrm{e}^{(17)}$.

Similar studies of printed educational technology validation using the CVI also needed some adjustments until achieving the final validated version. The replacement and explanation of terms considered inappropriate and puzzling, and the addition of relevant information and illustrations, were necessary for the elaboration of quality material(18-19).

As for reading motivation, the guidebook was considered very adequate, with a total CVI score of 0.95 , indicating an optimum level of agreement on this aspect among the specialists. The 
guidebook overall CVI score was 0.92 , and it was validated in content and format.

The contribution of the specialist nurses was fundamental for the conclusion of this process. Professional experience allied with academic background and teaching practice, as well as the unique input from marketing professionals familiar with the images and desktop publishing, allowed the positive adequacy of the material significantly, improving the content and format of the guidebook.

\section{Study limitations}

One of the challenges found in the guidebook design process was the difficulty of finding literature that specifically addressed the care of hemodialysis accesses, as well as having evaluators that were specialists in nephrology and who held a master's degree or $\mathrm{PhD}$. In addition, clinical validation, which will be carried out in a subsequent study, was not performed, but it is a fundamental step to tackle any questions about content clarity and to improve the material based on the understanding and the evaluation of the target audience.

\section{Contributions to the field}

The design of this material is intended to provide key information to renal patients undergoing hemodialysis, and help them with the daily maintenance care of vascular accesses for the treatment and prevention of complications.

Furthermore, it is also expected that this material may help to contribute to the nursing staff and serve as a support at the time of the admission of new patients, as well as to guide others who carry out this treatment for some time.

\section{CONCLUSION}

The current study allowed the design and validation of a guidebook for adult renal patients undergoing hemodialysis, "Hemodialysis: Care of Venous Accesses and Intercurrences at Home."

The purpose of the guidebook was to aid patients undergoing hemodialysis treatment, thus raising their awareness of the care of vascular accesses, and how to proceed in cases of intercurrences at home.

\section{REFERENCES}

1. Malta DC, Moura L, Prado RR, Escalante JC, Schmidt MI, Duncan BB. Mortalidade por doenças crônicas não transmissíveis no Brasil e suas regiões, 2000 a 2011. Epidemiol Serv Saúde [Internet]. 2014[cited 2017 Feb 12]; 23(4):599-608. Available from. www.scielo.br/pdf/ress/ v23n4/2237-9622-ress-23-04-00599.pdf

2. Silva AS, Silveira RS, Fernandes GFM, Lunardi VL, Backes VMS. Percepções e mudanças na qualidade de vida de pacientes submetidos à hemodiálise. Rev Bras Enferm [Internet]. 2011 [cited 2017 Feb 12];64(5):839-44. Available from: http://www.scielo.br/pdf/reben/v64n5/ a06v64n5.pdf

3. Sociedade Brasileira de Nefrologia. Censo 2016 [Internet]. 2016[cited 2017 Nov 12]. Available from: http://www.sbn.org.br/censo-brasileiro

4. Pessoa NRC, Linhares FMP. Hemodialysis patients with arteriovenous fistula: knowledge, attitude and practice. Esc Anna Nery [Internet]. 2015[cited 2017 Apr 12];19(1):73-9. Available from: http://www.scielo.br/pdf/ean/v19n1/en_1414-8145-ean-19-01-0073.pdf

5. Ministério da Saúde (BR). Diretrizes clínicas para o cuidado ao paciente renal crônica. Brasília: Ministério da Saúde; 2014.

6. Rosetti KAG, Tronchin DMR. Evaluation of the conformity of assistential practice in the maintenance of the temporary double-lumen dialysis catheter. Rev Latino-Am Enfermagem[Internet]. 2014 [cited 2018 Feb 12];22(1):129-35. Available from: http://www.scielo.br/pdf/rlae/ v22n1/0104-1169-rlae-22-01-00129.pdf

7. Nogueira FLL, Freitas LR, Cavalcante NS, Pennafort VPS. Perception of patients with chronic kidney disease regarding care towards their hemodialysis access. Cogitare Enferm [Internet]. 2016 [cited 2017 Dec 10];21(3):1-8. Available from: http://revistas.ufpr.br/cogitare/article/ view/45628/pdf_en

8. Ministério da Saúde (BR). Conselho Nacional de Saúde. Resolução 466/2012. Trata de pesquisas em seres humanos e atualiza a resolução 196 [Internet]. 2012 [cited 2017 Apr 12]. Available from: http://conselho.saude.gov.br/ultimas_noticias/2013/06_jun_14_publicada_ resolucao.html

9. Polit DF, Beck CT. Fundamentos da pesquisa em enfermagem. 7a ed. Porto Alegre: Artmed; 2011.

10. Echer IC. Elaboração de manuais de orientação para o cuidado em saúde. Rev Latino-Am Enfermagem [Internet]. 2005 [cited 2017 Feb 12];13(5):754-7. Available from: http://www.scielo.br/pdf/rlae/v13n5/v13n5a22.pdf

11. Fehring RJ. Methods to validate nursing diagnoses. Heart Lung [Internet]. 1987 [cited 2017 Feb 12];16(6Pt-1):625-9. Available from: https:// pdfs.semanticscholar.org/11f7/d8b02e02681433695c9e1724bd66c4d98636.pdf

12. Alexandre NMC, Coluci MZO. Validade de conteúdo nos processos de construção e adaptação de instrumentos de medidas. Ciênc Saúde Coletiva [Internet]. 2011 [cited 2017 Nov 11]; 16(7):3061-8. Available from: http://www.scielo.br/pdf/csc/v16n7/06.pdf

13. Neves Jr MA, Petnys A, Melo RC, Rabboni E. Vascular access for hemodialisys: what's new? J Vasc Bras [Internet]. 2013 [cited 2018 Feb 18];12(3):221-5. Available from: http://www.scielo.br/pdf/jvb/v12n3/en_1677-5449-jvb-12-03-00221.pdf

14. Góes FSN, Fonseca LMM, Camargo RAA, Oliveira JF, Felipe HF. Educational technology "Anatomy and Vital Signs": evaluation study of content, appearance and usability. J Med Inform [Internet]. 2015 [cited 2018 Feb 17];84(11):982-7. Available from: https://www. sciencedirect.com/science/article/pii/S1386505615300149?via\%3Dihub 
15. Sousa CS, Turrini RNT. Creating and validating educational material for patients undergoing orthognathic surgery. Asian Nurs Res [Internet]. 2012 [cited 2018 Feb 19]; 6(4):166-72. Available from: http://www.asian-nursingresearch.com/article/S1976-1317(12)00068-0/fulltext

16. Neves GBC, Andreto LM, Oliveira CR, Figueira MCS. Opinion of nurses on permanent education in a public hospital. Rev Enferm UFPE [Internet]. 2016 [cited 2017 Jul 09];10(5):1625-34. Available from: https://periodicos.ufpe.br/revistas/revistaenfermagem/article/ download/11158/12678

17. Cordeiro LI, Lopes TO, Lira LEA, Feitoza SMS, Bessa MEP, Pereira MLD, et al. Validation of educational booklet for HIV/Aids prevention in older adults. Rev Bras Enferm [Internet]. 2017 [cited 2018 Feb 19];70(4):775-82. Available from: http://www.scielo.br/pdf/reben/v70n4/0034-7167reben-70-04-0775.pdf

18. Lima AC, Bezerra KC, Sousa DM, Rocha JF, Oriá MO. Development and validation of a booklet for prevention of vertical HIV transmission. Acta Paul Enferm [Internet]. 2017 [cited 2018 Feb 19];30(2):181-9. Available from: http://www.scielo.br/pdf/ape/v30n2/en_1982-0194ape-30-02-0181.pdf

19. Medeiros JRR, Lima MA, Araújo LL, Galiza FT, Felipe GF, Caetano JA. Validation of educational technology for care in hemodialysis. Rev Enferm UFPE [Internet]. 2016 [cited 2017 Dec 09];10(11):3927-34. Available from: https://periodicos.ufpe.br/revistas/revistaenfermagem/ article/download/11474/13319 